Discussion Paper No. 574

\title{
TRADE INTEGRATION AND BUSINESS CYCLE SYNCHRONIZATION IN EAST ASIA
}

\author{
Kwanho Shin \\ and \\ Yunjong Wang
}

March 2003

The Institute of Social and Economic Research Osaka University

6-1 Mihogaoka, Ibaraki, Osaka 567-0047, Japan 


\title{
Trade Integration and Business Cycle Synchronization in East Asia
}

\author{
Kwanho Shin ${ }^{*}$ and Yunjong Wang ${ }^{* *}$
}

January 2003

\begin{abstract}
As trade integration deepens in East Asia, it is expected that there will be closer links in business cycles among East Asian countries. Theoretically, however, increased trade can lead business cycles across trading partners to shift in either direction: while inter-industry trade resulting in higher specialization would induce less synchronization, intra-industry trade could overturn this tendency. By using the data for twelve Asian economies, this paper finds that intra-industry trade is the major channel through which business cycles become synchronized among Asian economies, although increased trade itself does not necessarily lead to close business cycle coherence. This result has important implications for the prospects of a currency union in the region.
\end{abstract}

JEL Classification: E32, F36, F41

This paper was presented at the Asian Economic Panel meeting on October 8-9, 2002, at Columbia University, New York. We are grateful for Soyoung Kim, Warwick Mckibbin, Alan Siu, and Wing Thye Woo for helpful comments and suggestions. Byung Wook Ko provided excellent research assistance. Part of this paper was written while Kwanho Shin was affiliated as a visiting foreign scholar with Institute of Social and Economic Research, Osaka University.

* Department of Economics, Korea University, 1-5 Anam-Dong, Sungbuk-Gu, Seoul, Korea, khshin@korea.ac.kr

** Senior Research Fellow, KIEP, 300-4 Yomgok-Dong, Seocho-Gu, Seoul, Korea, yjwang@kiep.go.kr 


\section{Introduction}

The volume of trade in East Asian countries has continuously increased. The lowering of tariffs that started in the 1980s accelerated this trend of increasing trade worldwide. However, the growth in trade has been far speedier in East Asia than in any other region. A number of studies have observed that this rapid increase in trade is one of the key factors behind the region's rapid growth in income. ${ }^{1}$

Another important implication of increased trade is that countries involved with heavier trade integration are becoming more closely linked in macroeconomic performance. Thus, the influence of important trading partners is now essential to understanding the business cycle fluctuations of domestic economies. From a theoretical point of view, however, increased trade can lead business cycles across trading partners to be patterned in either direction - towards convergence or divergence. For example, if trade occurs mainly à la Heckscher-Ohlin or is of the Ricardian type, higher specialization would induce the industrial structures of the trading countries to diverge, resulting in less synchronized movements of business cycles. In contrast, if

\footnotetext{
${ }^{1}$ For the effects of trade on growth, see, among others, Frankel and Romer (1999).
} 
trade occurs mainly through intra-industry trade, this conclusion could be overturned. ${ }^{2}$

One of the main objectives of this paper is to empirically analyze how the business cycles of the Asian economies are influenced by increased trade within the region. As the regional trade began accelerating in the 1980s, trade linkages seemed to have an increasing influence on business cycle co-movements. As well, the possibility of free trade agreements in this region implies that this trend may persist even further.

Assessing business cycle co-movements of Asian countries has another very important implication in terms of evaluating the benefits and costs of adopting a common currency within the region. As pointed out in the seminal paper written by Robert Mundell (1961), the major cost of adopting a common currency is the loss of monetary independence. In adopting a common currency, all member countries must yield their independent monetary policies to a supranational authority. When asymmetric macroeconomic shocks occur across the member countries, monetary policy cannot be tailored to an individual economy's particular disturbances. Hence it is less costly for the economies to form a common currency if their business cycles are synchronized. In order to find potential candidates in the region for a currency union, it is necessary to be aware of the changing patterns of business cycle co-movements

\footnotetext{
${ }^{2}$ In section 2, we will explain the detailed mechanisms by which trade integration affects business cycle synchronization.
} 
among the East Asian countries. ${ }^{3}$ In this sense, knowing how trade integration will shape business cycles patterns among East Asian countries is of tremendous importance in gauging the prospects for a currency union in the region.

This paper is organized as follows. Section 2 discusses the mechanisms by which increased trade affects the pattern of business cycle co-movements. Section 3 describes data and statistical findings. Section 4 presents empirical analyses. In Section 5, we discuss the implication of our results on the prospects of a currency union in East Asia. The last section concludes.

\section{Trade Integration and Its Implications for Business Cycle}

\section{Synchronization}

Since trade is an important linkage between countries, many researchers have conjectured that it must play a crucial role in transmitting disturbances, influencing business cycle co-movements across countries. However, on the question of whether

\footnotetext{
${ }^{3}$ Mundell (1973) presented a new view of currency union as a means of smoothing shocks by better reserve pooling and portfolio diversification. The possibility of international risk-sharing implies that similarity of shocks is not a strict condition for sharing a common currency if all members of the currency union are financially integrated and hold claims on each others' outputs. This point has important implications for a debate about the size of a common currency area (Karlinger, 2002).
} 
increased trade leads to more or less correlation of business cycles across countries, there is no consensus. For example, Eichengreen (1992), Kenen (1969) and Krugman (1993) argued that as trade linkages increased, greater specialization of production would occur, resulting in less synchronization of business cycles. In particular, this is more so if business cycles are dominated by industry-specific technological shocks.

Frankel and Rose (1998) countered the above argument, insisting that if intraindustry trade was more pronounced than inter-industry trade, business cycles would become more positively correlated as trade became more integrated. As well, there are at least two additional important linkages that lead to a positive relation between business cycle co-movements and increased trade. First, if demand shocks drive a boom in one country, the effects can spill over to trading partners through an increased volume of imports. Second, increased trade may create a greater need for more coordinated fiscal as well as monetary policies, which synchronize policy shocks. Both of these linkages imply that increased trade leads to tighter business cycle comovements.

In sum, the theoretical implications of trade integration on business cycle comovements are not unambiguous; to test the validity of the theories, an empirical investigation is in order. Canova and Dellas (1993) investigated this issue and found 
that there was some evidence of trade affecting the transmission of disturbances across countries but it was not robust to the choices of the detrending method. Recently, Frankel and Rose (1998) found more positive results. Based on 21 industrialized countries, they found that the more countries traded with each other, the more correlated their business cycles were. That is, there is a strong positive relationship between the degree of bilateral trade intensity and the cross-country bilateral correlation of outputs. Following a similar method, Choe (2001) also finds that, based on ten East Asian countries, economic fluctuations are more synchronized as trade interdependence deepens in the region.

These results suggest that, as countries trade more, it becomes more advantageous to form a currency union not only in terms of benefits but also in terms of costs. This is what Frankel and Rose (1998) emphasized as the endogenous nature of the decision to join a currency union. In other words, a naïve examination of historical data may give a misleading picture of a country's eligibility for entry into a currency union since the economic structure is likely to change dramatically as a result of joining one. The results of Frankel and Rose can be interpreted to support an early introduction of a currency union; it will also decrease the costs of adopting a currency union by lowering asymmetric shocks through increased trade. Even a country that is not suited 
ex ante to joining a currency union can be justified ex post facto in joining one due to lowered asymmetrical shocks.

However, an important step is missing in this analysis. Frankel and Rose (1998) conjectured that their results are due to intra-industry trade, but did not further try to identify the channel through which increased trade affects business cycle comovements. ${ }^{4}$ In this paper, by extending Frankel and Rose's important contribution, we try to investigate how increased trade affects business cycle co-movements.

We call the four different channels affecting business cycle co-movements (1) inter-industry trade, (2) intra-industry trade, (3) demand spillovers, and (4) policy coordination channels. Only the first channel implies that increased trade leads to less synchronization of business cycles. The last three channels have in common that increased trade induces more synchronization of business cycles.

While it is apparent in Frankel and Rose's study that the first channel is not the one that facilitates convergence of business cycles, it is not clearly specified exactly which channel out of the last three channels drives their findings. To find the answer, it

\footnotetext{
${ }^{4}$ In their empirical work, Frankel and Rose (1998) do not control for variables other than bilateral trade intensity. Other researchers contend that controlling for sectoral similarity in the regressions lead to smaller coefficients on trade. However, Clark and van Wincoop (2001) and Otto, Voss, and Willard (2001) also control for industrial or sectoral similarity and the coefficients on trade are still statistically significant (Kose and Yi, 2002). Following Heathcote and Perri (2002), Kose and Yi (2002) find that under international financial autarky the model can generate stronger correlations for pairs of countries that trade more, but the increased correlation falls far short of the empirical findings.
} 
is necessary to consider these three channels separately and analyze how each one influences business cycle co-movements.

Recently, Fidrmuc (2001) has shown that, based on a cross-section analysis of OECD countries between 1990 and 1999, convergence of business cycles relates to intra-industry trade, but there is no direct relation between business cycles and bilateral trade intensity. Loayza, Lopez and Ubide (2001) analyze East Asia as a region and find significant short-run and long-run co-movement of business cycles. They find that this co-movement is based on the countries' highly similar trade structures. Based on a panel regression, Shin and Wang (2002) also find that intra-industry trade is the major channel through which Korea's business cycle becomes synchronized with that of eleven other Asian economies, although increased trade itself does not necessarily lead to close business cycle coherence. These recent empirical analyses suggest that business cycle co-movements are strengthened only when increased trade is accompanied by more intra-industry trade (Imbs, 2002).

In the next sections, we will investigate whether the findings from the case of Korea can be extended to other East Asian countries by identifying the most important channel leading to positive links between trade and business cycle co-movements in East Asia. 


\section{Data and Statistical Findings}

To measure output co-movements, annual data on real GDP are collected for twelve Asian countries over the period 1976-1997. The countries considered are five East Asian countries (China, Hong Kong, Japan, Korea and Taiwan), five ASEAN countries (Indonesia, Malaysia, the Philippines, Singapore and Thailand) and two other Asian countries (Bangladesh and India). ${ }^{5}$ The period after 1997 is excluded because we believe that the data is distorted by the Asian crisis and, by including it, the conventional measure of business cycle co-movements could be exaggerated. ${ }^{6}$ All the data are drawn from the IMF International Financial Statistics CD-Rom.

The trade volume data are collected from the IMF Direction of Trade Statistics CD-Rom. Industry-level trade data are available in Nicita and Olarreaga (2001), which reorganize the United Nations Statistics Department's Comtrade database through the World Bank's World Integrated Trade Solution (WITS) software. The industry disaggregation in the database follows the International Standard Industrial

\footnotetext{
${ }^{5}$ Five other ASEAN countries are excluded due to lack of data.
} 
Classification (ISIC) and is provided at the 2 digit level (9 industries), the 3 digit level (28 industries) and at the 4 digit level (81 industries) manufacturing industries only. The trade data includes both imports and exports, and mirror exports (reported by other trading partners) are obtained using WITS.

Table 1 shows changes in real GDP and the volume of trade in East Asian countries for the period between 1977 and 1997. The first column is the average growth rate in real GDP. The figures show that this region was in the midst of rapid growth before the Asian crisis, with the average growth rate over 7\% in China, Korea, Malaysia, Singapore and Taiwan and over $6 \%$ in Hong Kong and Indonesia. Japan, the Philippines and Bangladesh are exceptional cases with average growth rates lower than $4 \%$.

The second column is the average ratio of total trade (exports + imports) to GDP during the same period. This ratio is quite high for this region and it is generally higher for faster growing countries. We can see this by simply calculating the simple correlation coefficient between the first and the second columns, which turns out to be 0.31. This figure is consistent with a more formal analysis of the impacts of trade on growth done by, among others, Frankel and Romer (1999).

\footnotetext{
${ }^{6}$ Recently Lee, Park and Shin (2002) have found, for the latter period, that co-movements of outputs in East Asian countries are much more pronounced when the Asian crisis period is included.
} 
The third column is the average increase in percentage points for the ratio of total trade to GDP. ${ }^{7}$ This figure is positive in all countries except for Japan, which implies that total trade increased at a faster rate than GDP. Therefore, trade becomes more important as the volume of GDP increases. The fourth column is the ratio of regional trade to total trade. The figure is on average $44.9 \%$, which shows that regional trade is quite important. Finally, the fifth column is the average increase in percentage points for the ratio of regional trade to total trade. This figure is positive in all countries, which implies that, as time passes, regional trade becomes increasingly important for every country in the region.

Insert $<$ Table 1 $>$

To investigate how the bilateral trade intensity in each pair among the twelve Asian countries influences business cycle co-movements, we use three different proxies for bilateral trade intensity, following Frankel and Rose (1998): $w x_{t}, w m_{t}$ and $w t_{t}$. The first uses export data only, the second, import data, and the third, both export and import data. The variables are defined as follows:

\footnotetext{
${ }^{7}$ For example, if the ratio increases from $10 \%$ to $30 \%$ for 20 years, then the average increase is 1 percentage point.
} 


$$
\begin{aligned}
& w x_{t}(i, j)=\frac{x_{i j t}}{X_{i t}+X_{j t}} \\
& w m_{t}(i, j)=\frac{m_{i j t}}{M_{i t}+M_{j t}} \\
& w t_{t}(i, j)=\frac{x_{i j t}+m_{i j t}}{X_{i t}+M_{i t}+X_{j t}+M_{j t}}
\end{aligned}
$$

where $x_{i j t}$ denotes total nominal exports from country $i$ to country $j$ during period $t$; $m_{i j t}$ denotes total nominal imports from country $j$ to country $i$ during period $t$; and $X_{i}$ and $M_{i}$ denote total global exports and imports for country $i$. A higher value of any of these indices indicates greater trade intensity between country $i$ and country $j$.

A measure of intra-industry trade intensity is derived à la Grubel and Lloyd (1975). In constructing the measure, an important consideration is how detailed a classification of industries should be used. If we want to measure trade in more homogeneous sectors, we need to further disaggregate industries. However, as the industries are further disaggregated, the portion of intra-industry trade will shrink and eventually go to nil. Rather than a priori determining a proper industry classification, we construct three measures based on two-, three- and four-digit industry classifications following the International Standard Industrial Classification (ISIC). The constructed 
measure is

$$
I I T=1-\frac{\sum_{i}\left|x_{k j t}^{i}-m_{k j t}^{i}\right|}{\sum_{i}\left(x_{k j t}^{i}+m_{k j t}^{i}\right)}
$$

where $x_{i j t}^{I}$ is total nominal exports from country $i$ to country $j$ and $m_{i j t}^{I}$ is total nominal imports from country $j$ to country $i$. Depending on how an industry is classified, we can have three measures: $I I T_{2}$ for two-digit; $I I T_{3}$ for three-digit; and $I I T_{3}$ for four-digit classifications. Note that, since the second term on the right hand side in (4) decreases as more intra-industry trade occurs, we subtract it from 1 so that the index will monotonically increase as intra-industry trade increases.

Considering that any time-series change in trade patterns may influence the nature of business cycle co-movements, we divide the whole sample period into three sub-sample periods: 1976-83 (period 1), 1984-90 (period 2) and 1991-97 (period 3). We use two methods to derive cyclical parts of total real outputs by (1) first-differences in logarithms and (2) Hodrick-Prescott filter and then a simple correlation of the cyclical parts across countries is used as a proxy for business cycle co-movements.

In $<$ Table 2>, for each country, we report the average measure of output 
correlation, trade intensity and intra-industry trade with the other Asian countries in each period. The average correlation is based on a simple arithmetic mean for the correlation measures of each country with the other East Asian countries. For example, we calculate the correlation measures for Korea with each of the other eleven countries and use the mean as the measure for Korea. The first column is based on firstdifferences in logarithms and the second column, the Hodrick-Prescott filter. The third and fourth columns are the mean of trade intensity for each country against the other East Asian countries. The third column is a simple mean and the fourth column, a weighted mean using trade intensity measures as weights. The fifth and the sixth columns are the means of the intra-industry trade measure for each country against the other East Asian countries. The fifth column is a simple mean and the sixth column, a weighted mean using trade intensity measures as weights.

Insert $<$ Table 2>

Interestingly, there is no clear evidence that there has been an increase in comovements of business cycles recently. ${ }^{8}$ For both correlation measures, even for

\footnotetext{
${ }^{8}$ This fact is closely related to the fact that we have eliminated the period during the financial crisis and thereafter. If we include the period, the co-movement of business cycles substantially increases.
} 
countries where the correlation measure increases from period 1 to period 2 , it decreases back in period 3. This indicates that, while there is some weak evidence of increasing co-movements of business cycles among East Asian countries in the early period, this pattern does not seem sustained. On the other hand, trade intensity, whether based on exports, imports or total trade, has continuously increased. This shows that, as time passes, Asian countries are increasingly becoming important trading partners to each other. Another interesting phenomenon is that the intra-industry measure, whether based on 2-digit, 3-digit or 4-digit industries, has also continuously increased.

\section{Methodology and Results}

To more formally analyze this relationship, we set up the following equation and estimate the coefficients in the regression:

$\operatorname{corr}(i, j)_{\tau}=\alpha+\alpha_{1} *$ trade intensity $(i, j)_{\tau}+\alpha_{2} *$ intra-industry trade $(i, j)_{\tau}$

$+\alpha_{3} *$ fiscal policy coordination $(i, j)_{\tau}+\alpha_{4} *$ monetary policy coordination $(i, j)_{\tau}+\varepsilon_{i j \tau}$ 
where $\operatorname{corr}(i, j)_{\tau}$ refers to the correlation of output between country $i$ and country $j$ during period $\tau$. For trade intensity, we used three measures, $w x_{t}, w m_{t}$ and $w t_{t}$, and for intra-industry trade, another three measures $I I T_{2}, I I T_{3}$ and $I I T_{4}$. For fiscal policy coordination, we calculate the correlation of the ratio of budget deficit to GDP between country $i$ and country $j$. For monetary policy coordination, we consider the correlation coefficient of the M2 growth rates across each pair of countries.

Each term on the right hand side of equation (5) represents the channel through which increased trade influences co-movements of output across countries. The first term, trade intensity, indicates how demand spillovers influence business cycle correlation. Since demand spillovers increase as trade intensity increases, trade intensity can be used as a proxy of demand spillovers. The second term, intra-industry trade, indicates how co-movements of output are influenced by intra-industry trade. The third and the fourth terms indicate how policy coordination, either fiscal or monetary policy, affect co-movements. Finally, if increased trade is made mainly through inter-industry trade and if this channel dominates the other channels, then the coefficient of the first term should be negative. In this way we can identify the most 
important channel of trade influencing co-movement of outputs across countries. ${ }^{9}$

Frankel and Rose (1998) also estimated an equation similar to (5), but they included only the first term in their regression. They pointed out that a simple OLS regression would generate a biased estimation due to an endogeneity problem. This problem arises because countries are likely to link their currencies deliberately to those of their most important trading partners in order to capture gains associated with greater exchange rate stability. That is, trading partners lose the ability to set policies independently of their neighbors and this tied policy coordination could result in a spurious association between trade intensity and business cycle co-movements. They suggested using 1) log of distance; 2) a dummy variable for common border; and 3) a dummy variable for common language for instrumental variables.

There are two problems in adopting their methodology to our case. First, these instrumental variables are expected to be highly correlated to trade intensity, but not to intra-industry trade. It is, however, difficult to find appropriate instrumental variables for intra-industry trade. Second, our regression results are based on a panel regression that includes times series variations as well as cross-section variations. Since these

\footnotetext{
${ }^{9}$ This approach cannot identify different ways by which various shocks influence the co-movements. For example, some shocks originating from one country can have asymmetric effects on the other. To fully incorporate the various aspects of the shocks, a structural model should be developed, which is beyond the analysis covered in the paper.
} 
instrumental variables do not change over time, we cannot estimate all the coefficients of time-varying variables.

Imbs (1998) suggests that the above problem cannot be solved through an instrumental variable estimation because the real problem is not an endogeneity problem but one of omitted variables. He argued that, in a panel regression, unobserved components of time-invariable characteristics for each country can be handled by introducing fixed effects. However, we believe that a panel regression with fixed effects cannot entirely solve the problem pointed out by Frankel and Rose. To tackle the problem directly, we need to introduce the omitted variables that cause the spurious relationship between trade intensity and co-movements.

In equation (5), we try to control the effects of policy shocks by explicitly considering two types of policy coordination. In measuring the degree of fiscal policy coordination, we first calculate the ratio of budget deficit to GDP for each country and then calculate the correlation coefficient of this ratio across each pair of countries. In measuring the degree of monetary policy coordination we follow similar steps: we first calculate the M2 growth rate for each country and calculate the correlation coefficient of the M2 growth rates across each pair of countries. ${ }^{10}$

\footnotetext{
${ }^{10}$ Clark and van Wincoop (2001) used a different proxy for policy coordination. They measured the difference in the monetary policy of two countries by the standard deviation of the interest rate
} 
The regression results with cyclical parts generated by first-differences in logarithms are summarized in $<$ Table $3>{ }^{11}$ In $<$ Table $3-\mathrm{A}>$, the regression results from pooling the three periods are reported. In columns 1 through 6 , either trade intensity or intra-industry trade is used as a regressor. In columns 7 through 9, both trade intensity and intra-industry trade are included as regressors. Since the results for intra-industry trade in columns 4 through 6 are very similar for the different measures of intra-industry trade, only $\mathrm{IIT}_{4}$ is used for the measure of intra-industry trade in the estimation in columns 7 through 9. Indeed regression results using $I I T_{2}$ or $I I T_{3}$ instead of $I I T_{4}$ are very similar and hence not reported.

The regression results in $<$ Table $3-\mathrm{A}>$ indicate that, as expected, the estimated coefficient for trade intensity is positive and statistically significant either at $1 \%$ or at 5\%. Furthermore the coefficient for intra-industry trade is also positive and statistically significant indicating a positive relationship between output correlation and intraindustry trade. However, when we include both trade intensity and intra-industry trade, the coefficient of intra-industry trade, though still positive, becomes statistically

differential and the difference in fiscal policy by the budget deficit differential. In our case, the interest rate is not available for many countries and hence we used the monetary growth rate instead. Further using the standard deviation instead of the correlation coefficient does not change our major results in Section 4.

${ }^{11}$ We have also performed the regression analyses with cyclical parts generated by the Hodrick-Prescott filter. In this case the fitting of the model is generally poorer than in the case with first differences in logarithms and more coefficients are not statistically significant. However the overall conclusions are similar. These results can be obtained from the authors upon request. 
insignificant. The coefficients for policy coordination are of the right sign, but only the one for monetary policy coordination is statistically significant.

In $<$ Table $3-\mathrm{B}>$, the results for a panel regression with fixed effects are reported. Compared to the OLS estimation with pooling, the estimation with fixed effects eliminates unobservable country-specific components and is more appropriate for analyzing the effects of time series patterns of trade. In this case, the coefficient estimates for intra-industry trade are, in most cases, statistically significant at $10 \%$ and quite robust across different specifications. Furthermore, even after including the trade intensity measure, the estimates change very little, with the same level of significance maintained. On the other hand, the coefficient estimates for trade intensity are not statistically significant at the $10 \%$ level. Even when only trade intensity is used as a regressor, the coefficient estimates are in the right sign, but they are not statistically significant. When both trade intensity and intra-industry trade variables are used as regressors, the coefficient estimates for trade intensity are still insignificant at $10 \%$.

Given that panel regression results generate a better specification of the model, our results suggest that intra-industry trade might be a major source of business cycle co-movements. Unlike Frankel and Rose (1998), our results indicate that increasing trade itself does not induce synchronization of business cycles. Especially, if increasing 
trade occurs mainly across different industries, it does not foster co-movements of outputs with trading partners.

Insert $<$ Table 3 $>$

We have also performed various robust checks against our specification and generally arrived at the same conclusion. ${ }^{12}$ First, one might argue that Japan is the most heavily involved in trade integration in the region and the exclusion of Japan would substantially weaken our results. In $<$ Table $4>$ the same regression results are reported with Japan excluded from the sample. While $<$ Table 4 .A $>$ leads to generally the same conclusion, contrary to our expectations, <Table 4.B $>$ significantly enhances our arguments. In $<$ Table 4.B $>$, whose specification is more favored than that of $<$ Table 4.A $>$, we find that the coefficients of intra-industry trade are significant even at $5 \%$ in columns 7 through 9 where trade intensity measures are included as well. In contrast, the coefficients of trade intensity are not significant and t-ratios are generally lower than those in $<$ Table $3>$.

\footnotetext{
${ }^{12}$ As explained earlier, the general conclusion from the Hodrick-Prescott filter results is similar.
} 
Insert $<$ Table $4>$

Second, we further exclude Hong Kong and Singapore in our sample, because a considerable portion of trade for these countries is attributable simply to their intermediatiation of trade between other countries. The regression results for this case are reported in $\langle$ Table $5>$. While the significance is weakened as the sample size shrinks, generally the same conclusion is preserved: in $<$ Table $5 . \mathrm{B}>$, the coefficients for intra-industry trade are statistically more significant than those for trade intensity. In this sense we can conclude that co-movements of business cycles are influenced more by intra-industry trade than the volume of trade itself.

Insert $<$ Table 5 $>$

\section{Implications for a Currency Union}

The recent Asian currency crisis has induced Asian countries to seriously consider forming a common currency area as an alternative to the past soft-peg as well as the 
current floating exchange rate regimes. The successful launch of the euro in 1999 and its claimed benefits are also encouraging this movement. For many developing countries in the region with common export markets, the fluctuation of their bilateral exchange rates critically affects the competitiveness of their exports. Further, as trade integration among Asian economies accelerates, there will be more pressure, from inside, to enhance exchange rate stability among East Asian currencies. By establishing a common currency area, these countries can stabilize their overall export competitiveness and enhance the benefits from further trade integration.

According to Rose (2000), membership in a currency union, ceteris paribus, more than triples bilateral trade among member countries. ${ }^{13}$ This is true even after controlling for a number of other factors that might affect trade through the gravity model, which shows that trade between a pair of countries is proportional to their combined incomes, and inversely proportional to the distance between them. These gains from trade are made even without decreasing trade with non-member countries. Since increasing trade by a factor of three is no easy feat, many people have questioned Rose's estimate. Despite the critics, Rose and his coauthors' subsequent works suggest

\footnotetext{
13 Rose (2000) emphasizes a phenomenon known as "home bias" in international trade - much more intense trade inside countries than between countries. McCallum (1995) quantifies the size of the intraregional bias at more than twenty to one, finding that trade between two Canadian provinces is more than 20 times larger than trade between a comparable Canadian province/American state pair. Rose seems to regard this home bias effect as one of the main driving forces for increasing trade through currency union.
} 
that the increase in trade due to a currency union would be substantial.

Frankel and Rose (1998) emphasized that the fact that trade significantly increases after the formation of a currency union has important implications: the decision to join a monetary union has an endogenous nature. In other words, a cursory review of historical data may give a misleading picture of a country's eligibility for entry into a monetary union since the economic structure is likely to change dramatically as a result of joining the monetary union. Especially, increased trade affects the nature of co-movements among member countries, which is the most important element in gauging the costs of joining a currency union. These results can be interpreted to encourage the early introduction of a monetary union; it will decrease the costs of adopting a monetary union by lowering asymmetric shocks through increased trade. Even a country that is not suited ex ante to joining a monetary union can be justified ex post facto in joining one due to lowered asymmetrical shocks.

However, our findings suggest that the above argument is not generally true: business cycle co-movements are strengthened only when increased trade is accompanied by more intra-industry trade. Therefore, caution should be exercised in searching for appropriate partners for a currency union. While trade may increase following a currency union, if the increased trade is mainly inter-industry trade, 
business cycle co-movements can be weakened, making the currency union undesirable ex post facto.

Most empirical studies widely confirm the hypothesis that measures of intraindustry trade relative to inter-industry trade decline steeply as the distance between the trading partners increases. ${ }^{14}$ In light of this finding, intra-industry trade among geographically neighboring East Asian countries should be high. However, as shown in $<$ Table 6>, the intra-industry trade index in East Asia was much lower than that of Europe in 1980: 31.3 vs. 60.8 for IIT-2, 22.6 vs. 52.0 for IIT-3 and 20.0 vs. 46.6 for IIT4. This reflects the fact that the European countries had more homogenous industry structures in 1980 compared to East Asian countries. ${ }^{15}$ The index is monotonically increasing in both regions, but the speed is much faster in East Asia, so that the gap becomes much smaller in 1999: 56.1 vs. 67.9 for IIT-2, 51.1 vs. 58.9 for IIT-3 and 45.0 vs. 52.3 for IIT-4. This is good news for a currency union because trade in East Asia not only increases overall but it also occurs more and more within the same industries. If this tendency continues, then business cycle co-movements can be strengthened.

\footnotetext{
${ }^{14}$ See for example, Balassa (1986a, 1986b), Balassa and Bauwens (1987, 1988), Bergstrand (1983), Culem and Lundberg (1986), Hummels and Levinsohn (1995), and Stone and Lee (1995).

${ }^{15}$ Rice, Stewart, and Venables (2002), by using the data of 22 OECD countries, find that closer countries tend to have more similar structures of underlying export supply and import demand, and as a consequence, intra-industry trade tends to be relatively high between close (and hence similar) countries.
} 
When we examine individual countries, the intra-industry trade index is low in China, Indonesia, Japan, Korea and Thailand - below the average in the region. Furthermore, the index is increasing in most East Asian countries except for Hong Kong, China and Korea. If this trend continues for these countries, then they are likely to have more asymmetric shocks over the business cycle, which may prevent them from joining a monetary union. However, it is very difficult to predict how this trend will change in individual countries without analyzing what factors contribute to fostering inter- or intra-industry trade. This will be a good subject for future research.

Insert $<$ Table 6>

\section{Conclusion}

Increasing trade among Asian countries induces a higher degree of economic integration within the region. In this sense the business cycle of a country is expected to be continuously influenced by other economies in Asia, especially as trade within the region grows relatively more important. In particular, we have found in this paper that 
intra-industry trade is the major channel though which the business cycles of East Asian economies become synchronized.

Unlike other studies in the literature, however, we find that increasing trade itself does not necessarily lead to more synchronization of business cycles. This has important implications in considering the adoption of a currency union. We expect that the costs of joining a currency union will severely diminish only when intra-industry trade dominates afterwards. 


\section{References}

Alesina, Alberto and Robert J. Barro, 2002, "Currency Unions," Quarterly Journal of Economics 117, May, 409-436.

Balassa, Bela, 1986a, "Intra-industry Trade among Exporters of Manufactured Goods," in Imperfect Competition and International Trade, edited by D. Greenaway and P.K.M. Tharakan, Brighton: Wheatsheaf: 108-128.

Balassa, Bela, 1986b, "Intra-industry Specialization: A Cross-Country Analysis," European Economic Review 30, 27-42.

Balassa, Bela, and Luc Bauwens, 1987, "Intra-industry Specialization in a MultiCountry and Multi-industry Framework," The Economic Journal 97, 923-939.

Balassa, Bela, and Luc Bauwens, 1988, “The Determinants of Intra-European Trade in Manufactured Goods," European Economic Review 32, 1421-1437.

Bayoumi, Tamin and Barry Eichengreen, 1994, "One Money or Many? Analyzing the Prospects of Monetary Unification in Various Parts of the World," Princeton Studies in International Finance No 76.

Bergstrand, Jeffrey H., 1983, "Measurement and Determinants of Intra-industry International Trade," in Imperfect Competition and International Trade, edited by 
D. Greenaway and P.K.M. Tharakan, Brighton: Wheatsheaf: pp. 201-262.

Canova, Fabio and Harris Dellas, 1993, "Trade Interdependence and the International Business Cycle," Journal of International Economics 34, 23-47.

Choe, Jongil, 2001, “An Impact of Economic Integration through Trade: On Business Cycles for 10 East Asian Countries," Journal of Asian Economics 12, 569-586.

Clark, Todd and Eric van Wincoop, 2001, "Borders and Business Cycles," Journal of International Economics 55, 59-85.

Culem, Claudy G. and Lars Lundberg, 1997, “The Product Pattern of Intra-industry Trade: Stability among Countries and over Time," Weltwirtschaftliches Archiv 122, 113-130.

Eichengreen, Barry, 1992, “Should the Maastricht Treaty Be Saved?” Princeton Studies in International Finance, No. 74, International Finance Section, Princeton University.

Fidrmuc, Jarko, 2001, "The Endogeneity of Optimum Currency Area Criteria, Intraindustry Trade and EMU Enlargement,” BOFIT Discussion Papers No.8.

Frankel, Jeffrey, and David Romer, 1999, "Does Trade Cause Growth?" American Economic Review 89, 379-399.

Frankel, Jeffrey and Andrew Rose, 1998, "The Endogeneity of the Optimum Currency 
Area Criteria," The Economic Journal 108, 1009-1025.

Frankel, Jeffrey, and Andrew Rose, 2002, “An Estimate of the Effect of Currency Unions on Trade and Growth," The Quarterly Journal of Economics 117, 10091025

Grubel, Herbert G. and Peter J. Lloyd, 1975, Intra-industry Trade: The Theory and Measurement of International Trade in Differentiated Products, London: MacMillan Press.

Heathcote, Jonathan and Fabrizio Perri, 2002, "Financial Autarky and International Business Cycles," Journal of Monetary Economics 49, 601-628.

Hummels, David and James Levinshon, 1995, "Monopolistic Competition and International Trade: Reconsidering the Evidence," The Quarterly Journal of Economics 110, 799-836.

Imbs, Jean, 1998, "Fluctuations, Bilateral Trade and the Exchange Rate Regime," London Business School, mimeo.

Imbs, Jean, 2002, "Trade, Finance, Specialization and Synchronization," London Business School, mimeo.

Karlinger, Liliane, 2002, “The Impact of Common Currencies on Financial Markets: A Literature Review and Evidence from the Euro Area," Bank of Canada Working 
Paper 2002-35, November.

Kenen, Peter, 1969, “The Theory of Optimum Currency Areas: An Eclectic View,” in R.

Mundell and A. Swoboda eds., Monetary Problems in the International Economy, Chicago: University of Chicago Press.

Kose, M. Ayhan and Kei-Mu Yi, 2002, "The Trade Comovement Problem in International Macroeconomics," mimeo.

Krugman, Paul, 1993, "Lessons of Massachusetts for EMU," in F. Giavazzi and F. Torres, eds., The Transition to Economic and Monetary Union in Europe, pp.241261, Cambridge University Press, New York.

Lee, Jong-wha, Yung Chul Park and Kwanho Shin, 2002, “A Currency Union in East Asia," Korea University, mimeo.

Loayza, Norman, Humberto Lopez, and Angel Ubide, 2001, "Co-Movements and Sectoral Interdependence for Latin America, East Asia, and Europe," IMF Staff Papers 48, 367-395.

McCallum, John, 1995, "National Borders Matter: Canada-U.S. Regional Trade Patterns," American Economic Review 85, 615-623.

Mundell, Robert, 1961, “A Theory of Optimum Currency Area,” American Economic Review 60, 657-665. 
Mundell, Robert, 1973, "Uncommon Arguments for Common Currencies," in H.G.

Johnson and A.K. Swoboda, eds., The Economics of Common Currencies, 114132.

Nicita, Alessandro and Marcelo Olarreaga, 2001, “Trade and Production: 1976-1999," Working Paper No.??, the World Bank.

Otto, Glenn, Graham Voss, and Luke Willard, 2001, “Understanding OECD Output Correlations," Working paper, University of New South Wales.

Rice, Patricia, Martin Stewart, and Anthony J. Venables, 2002, “The Geography of Intra-industry Trade: Empirics,” CEPR Discussion Paper No. 3368, Center for Economic Policy Research.

Rodriguez, Francisco and Dani Rodrik, 2000, “Trade Policy and Economic Growth: A Skeptic's Guide to the Cross-National Evidence.” Macroeconomics Annual 2000, edited by Ben Bernanke and Kenneth Rogoff, MIT Press for NBER.

Rose, Andrew, 2000, “One Money, One Market? The Effect of Common Currencies on International Trade," Economic Policy 30, 435-448.

Shin, Kwanho and Yunjong Wang, 2002, “Trade Integration and Business Cycle Comovements: The Case of Korea with Other Asian Countries," KIEP Working Paper No. 02-08, Korea Institute for International Economic Policy. 
Stone, Joe A. and Hyun Hoon Lee, 1995, "Determinants of Intra-industry Trade: A Longitudinal, Cross-country Analysis," Weltwirtschaftliches Archiv 131, 67-85. 
Table 1. GDP Growth, Trade-GDP Ratio and Regional-World Trade Ratio

\begin{tabular}{c|c|c|c|c|c}
\hline & $\begin{array}{c}\text { GDP growth } \\
(\%)\end{array}$ & $\begin{array}{c}\text { T/GDP mean } \\
(\%)\end{array}$ & $\begin{array}{c}\text { T/GDP growth } \\
\text { (\% point) }\end{array}$ & $\begin{array}{c}\mathrm{R} / \mathrm{W} \\
\text { mean (\%) }\end{array}$ & $\begin{array}{c}\mathrm{R} / \mathrm{W} \\
\text { Growth (\%) }\end{array}$ \\
\hline BGD & 3.9 & 24.6 & 0.9 & 30.3 & 1.2 \\
\hline CHN & 9.3 & 27 & 6.2 & 51.4 & 0.9 \\
\hline HKG & 6.6 & 234.1 & 4.1 & 53.6 & 1.4 \\
\hline IDN & 6.2 & 16.7 & 0.4 & 56.8 & 0.1 \\
\hline IND & 5 & 49.4 & 0.6 & 19.7 & 0.4 \\
\hline JPN & 3.3 & 21.2 & -0.2 & 27.4 & 1.1 \\
\hline KOR & 7.2 & 64.6 & 0.3 & 36.4 & 0.4 \\
\hline MYS & 7.1 & 132 & 4.6 & 55.5 & 0.5 \\
\hline PHL & 2.8 & 59.3 & 3.3 & 40.2 & 0.7 \\
\hline SGP & 7.2 & 291.3 & -1 & 48.1 & 0.7 \\
\hline THA & 7.1 & 64.3 & 2.4 & 46.1 & 0.4 \\
\hline TWN & 7.6 & 93 & -0.05 & 73.8 & 1.7 \\
\hline Average & 6.1 & 89.8 & 1.8 & 44.9 & 0.8 \\
\hline Not: & & & &
\end{tabular}

Note: 1 . The values less than $1 / 10$ are all dropped.

2. In most cases, the sample period is 1977 to 1997; For China, it is 1979 to 1997. 
Table 2. On Sub-Sample Averages of the Variables

\begin{tabular}{|c|c|c|c|c|c|c|c|}
\hline & & corr_y & corr_y & wt & wt & IIT-4 & IIT-4 \\
\hline & & (LD) & (HP) & $\begin{array}{c}\text { (simple } \\
\text { average) }\end{array}$ & $\begin{array}{l}\text { (weigted } \\
\text { average) }\end{array}$ & $\begin{array}{c}\text { (simple } \\
\text { average) }\end{array}$ & $\begin{array}{l}\text { (weigted } \\
\text { average) }\end{array}$ \\
\hline \multirow[t]{3}{*}{ BGD } & Period 1 & 0.1177 & 0.1697 & 0.0016 & 0.0004 & 0.029 & 0.0105 \\
\hline & Period 2 & -0.1 & -0.25 & 0.0016 & 0.0006 & 0.0265 & 0.0172 \\
\hline & Period 3 & -0.2315 & -0.1827 & 0.0018 & 0.0011 & 0.044 & 0.0207 \\
\hline \multirow[t]{3}{*}{$\mathrm{CHN}$} & Period 1 & -0.244 & 0.0554 & 0.0172 & 0.0193 & n.a. & n.a. \\
\hline & Period 2 & -0.2727 & -0.3737 & 0.0233 & 0.0389 & 0.2102 & 0.1973 \\
\hline & Period 3 & 0.1591 & 0.0805 & 0.0212 & 0.0314 & 0.2959 & 0.2273 \\
\hline \multirow[t]{3}{*}{$\mathrm{HKG}$} & Period 1 & 0.3562 & 0.1745 & 0.0182 & 0.0161 & 0.5714 & 0.1961 \\
\hline & Period 2 & 0.1872 & 0.2211 & 0.0254 & 0.0461 & 0.5904 & 0.3192 \\
\hline & Period 3 & -0.0589 & -0.0695 & 0.0324 & 0.0772 & 0.5733 & 0.3701 \\
\hline \multirow[t]{3}{*}{ IDN } & Period 1 & 0.3049 & 0.0984 & 0.0126 & 0.0228 & 0.0554 & 0.033 \\
\hline & Period 2 & 0.2084 & 0.0509 & 0.0093 & 0.014 & 0.1475 & 0.0571 \\
\hline & Period 3 & 0.2663 & 0.1755 & 0.0107 & 0.0111 & 0.2444 & 0.1047 \\
\hline \multirow[t]{3}{*}{ IND } & Period 1 & -0.1248 & -0.1589 & 0.004 & 0.0011 & 0.0618 & 0.0083 \\
\hline & Period 2 & 0.1629 & 0.2912 & 0.0044 & 0.0014 & 0.1339 & 0.0236 \\
\hline & Period 3 & 0.1024 & 0.0673 & 0.0044 & 0.001 & 0.2428 & 0.0504 \\
\hline \multirow[t]{3}{*}{ JPN } & Period 1 & 0.3506 & 0.1738 & 0.0199 & 0.0069 & 0.1281 & 0.0349 \\
\hline & Period 2 & 0.0564 & 0.2637 & 0.0214 & 0.008 & 0.1729 & 0.0565 \\
\hline & Period 3 & -0.0954 & -0.1932 & 0.0266 & 0.0128 & 0.2632 & 0.1111 \\
\hline \multirow[t]{3}{*}{ KOR } & Period 1 & -0.0144 & -0.0471 & 0.0009 & 0.0009 & 0.174 & 0.0899 \\
\hline & Period 2 & 0.2251 & 0.2579 & 0.0011 & 0.0011 & 0.3218 & 0.1268 \\
\hline & Period 3 & 0.0876 & -0.0241 & 0.0016 & 0.0012 & 0.3192 & 0.1654 \\
\hline \multirow[t]{3}{*}{ MYS } & Period 1 & 0.2025 & -0.1685 & 0.0134 & 0.0144 & 0.1822 & 0.1163 \\
\hline & Period 2 & 0.3204 & 0.0663 & 0.0142 & 0.0159 & 0.2794 & 0.1957 \\
\hline & Period 3 & 0.2637 & 0.1487 & 0.0171 & 0.0202 & 0.3875 & 0.2681 \\
\hline \multirow[t]{3}{*}{ PHL } & Period 1 & 0.2537 & -0.2462 & 0.0048 & 0.0032 & 0.1263 & 0.0548 \\
\hline & Period 2 & 0.268 & 0.3907 & 0.0046 & 0.0025 & 0.2222 & 0.1061 \\
\hline & Period 3 & -0.1281 & -0.122 & 0.0057 & 0.0039 & 0.2821 & 0.1577 \\
\hline \multirow[t]{3}{*}{ SGP } & Period 1 & 0.1273 & -0.2022 & 0.0235 & 0.0186 & 0.2321 & 0.1152 \\
\hline & Period 2 & 0.3641 & 0.1876 & 0.0228 & 0.0196 & 0.3444 & 0.1813 \\
\hline & Period 3 & 0.2888 & 0.1937 & 0.0259 & 0.0256 & 0.4195 & 0.2721 \\
\hline \multirow[t]{3}{*}{ THA } & Period 1 & 0.2598 & 0.101 & 0.0073 & 0.005 & 0.1228 & 0.0486 \\
\hline & Period 2 & 0.2995 & 0.3445 & 0.0088 & 0.0066 & 0.165 & 0.0883 \\
\hline & Period 3 & 0.2849 & 0.0793 & 0.0123 & 0.0117 & 0.3087 & 0.1748 \\
\hline \multirow[t]{3}{*}{ TWN } & Period 1 & 0.3935 & 0.163 & 0.0152 & 0.0158 & 0.177 & 0.1226 \\
\hline & Period 2 & 0.0872 & 0.2214 & 0.016 & 0.0198 & 0.2455 & 0.183 \\
\hline & Period 3 & -0.0797 & -0.1215 & 0.0201 & 0.0347 & 0.3387 & 0.293 \\
\hline
\end{tabular}

Note: The fractions are rounded off to-four decimal places, before being transformed into a percent unit. 
Table 3. The Effects of Trade Integration on Business Cycle Co-movements.

3.A Pooled Regression

\begin{tabular}{|c|c|c|c|c|c|c|c|c|c|}
\hline & 1 & 2 & 3 & 4 & 5 & 6 & 7 & 8 & 9 \\
\hline \multirow[t]{2}{*}{$\mathrm{wX}$} & $4.183 * * *$ & & & & & & $3.306^{* *}$ & & \\
\hline & $(2.87)$ & & & & & & $(2.17)$ & & \\
\hline \multirow[t]{2}{*}{ wm } & & $3.071 * *$ & & & & & & $2.244 *$ & \\
\hline & & $(2.57)$ & & & & & & $(1.78)$ & \\
\hline \multirow[t]{2}{*}{ wt } & & & $4.022 * * *$ & & & & & & $3.116 * *$ \\
\hline & & & $(2.91)$ & & & & & & $(2.13)$ \\
\hline \multirow[t]{2}{*}{ IIT_2 } & & & & $0.374 * *$ & & & & & \\
\hline & & & & $(2.24)$ & & & & & \\
\hline \multirow[t]{2}{*}{ IIT_3 } & & & & & $0.384 * *$ & & & & \\
\hline & & & & & $(2.25)$ & & & & \\
\hline \multirow[t]{2}{*}{ IIT_4 } & & & & & & $0.399 * *$ & 0.291 & $0.312 *$ & 0.288 \\
\hline & & & & & & $(2.27)$ & $(1.61)$ & $(1.72)$ & $(1.59)$ \\
\hline \multirow[t]{2}{*}{ bd_corr } & 0.077 & 0.064 & 0.073 & 0.061 & 0.064 & 0.07 & 0.08 & 0.07 & 0.08 \\
\hline & $(1.15)$ & $(0.96)$ & $(0.90)$ & $(0.90)$ & $(0.94)$ & $(1.00)$ & $(1.18)$ & $(1.05)$ & $(1.15)$ \\
\hline \multirow[t]{2}{*}{ m_corr } & $0.255^{* * *}$ & $0.279 * * *$ & $0.262 * * *$ & $0.272 * * *$ & $0.268 * * *$ & $0.266 * * *$ & $0.241 * * *$ & $0.261 * * *$ & $0.248 * * *$ \\
\hline & (3.24) & $(3.58)$ & (3.37) & $(3.45)$ & $(3.39)$ & $(3.37)$ & $(3.06)$ & $(3.32)$ & (3.16) \\
\hline \multirow{3}{*}{$\begin{array}{c}\text { \# of obs. } \\
\mathrm{R}^{\wedge} 2 \\
\text { Root MSE }\end{array}$} & 166 & 167 & 167 & 163 & 163 & 163 & 163 & 163 & 163 \\
\hline & 0.13 & 0.12 & 0.13 & 0.11 & 0.11 & 0.11 & 0.14 & 0.13 & 0.14 \\
\hline & 0.42 & 0.42 & 0.42 & 0.43 & 0.43 & 0.43 & 0.42 & 0.42 & 0.42 \\
\hline
\end{tabular}

Note: (i) The dependent variable is output correlation between two countries for the three sub-sample periods, 197683 (period 1), 1984-90 (period 2) and 1991-97 (period 3). The trade intensity measures, wx, wm and wt are defined as in equation (1), (2) and (3), based on exports, imports and total trade respectively. The intraindustry trade measure, IIT_2, IIT_3, and IIT_4, are defined as in equation (4), based on ISIC 2, 3 and 4 digit classifications. Two added regressors, bd_corr and $\mathrm{m}_{-}$corr are measures of the fiscal and the monetary policy coordination respectively.

(ii) The values in parentheses are t-ratios. The significance of the estimated coefficients are denoted by * indicating significance at $10 \%, * *$, at $5 \%$ and $* * *$, at $1 \%$.

3. B Panel Regression: Fixed Effects

\begin{tabular}{|c|c|c|c|c|c|c|c|c|c|}
\hline & 1 & 2 & 3 & 4 & 5 & 6 & 7 & 8 & 9 \\
\hline \multirow[t]{2}{*}{$\mathrm{wx}$} & 8.640 & & & & & & 6.247 & & \\
\hline & $(1.25)$ & & & & & & $(0.84)$ & & \\
\hline \multirow[t]{2}{*}{ wm } & & 5.133 & & & & & & 5.384 & \\
\hline & & (1.27) & & & & & & $(1.26)$ & \\
\hline \multirow[t]{2}{*}{ wt } & & & 9.100 & & & & & & 7.665 \\
\hline & & & $(1.32)$ & & & & & & $(1.00)$ \\
\hline \multirow[t]{2}{*}{ intrm_2 } & & & & 0.427 & & & & & \\
\hline & & & & $(1.22)$ & & & & & \\
\hline \multirow[t]{2}{*}{ intrm_3 } & & & & & $0.632 *$ & & & & \\
\hline & & & & & $(1.72)$ & & & & \\
\hline \multirow[t]{2}{*}{ intrm_4 } & & & & & & $0.800^{*}$ & 0.707 & $0.787 *$ & $0.704 *$ \\
\hline & & & & & & (1.94) & $(1.65)$ & $(1.91)$ & (1.66) \\
\hline \multirow[t]{2}{*}{ bd_corr } & 0.08 & 0.073 & 0.076 & 0.063 & 0.063 & 0.07 & 0.08 & 0.08 & 0.08 \\
\hline & $(0.92)$ & $(0.84)$ & $(0.88)$ & $(0.71)$ & $(0.72)$ & $(0.79)$ & $(0.89)$ & $(0.88)$ & $(0.90)$ \\
\hline \multirow[t]{2}{*}{ m_corr } & 0.093 & 0.102 & 0.097 & 0.090 & 0.090 & 0.084 & 0.087 & 0.093 & 0.088 \\
\hline & $(0.99)$ & (1.09) & $(1.05)$ & $(0.93)$ & $(0.94)$ & $(0.88)$ & $(0.91)$ & $(0.98)$ & $(0.93)$ \\
\hline \multirow{3}{*}{$\begin{array}{c}\# \text { of obs. } \\
\text { overall } \\
R^{\wedge} 2 \\
\text { sigma_e }\end{array}$} & 166 & 167 & 167 & 163 & 163 & 163 & 163 & 163 & 163 \\
\hline & 0.09 & 0.08 & 0.08 & 0.08 & 0.07 & 0.07 & 0.10 & 0.08 & 0.09 \\
\hline & 0.40 & 0.40 & 0.40 & 0.41 & 0.41 & 0.41 & 0.41 & 0.40 & 0.41 \\
\hline
\end{tabular}

Note: See the note to Table 3.A. 
Table 4. The Effects of Trade Integration on Business Cycle Co-movements (Japan excluded)

4.A Pooled Regression

\begin{tabular}{|c|c|c|c|c|c|c|c|c|c|}
\hline & 1 & 2 & 3 & 4 & 5 & 6 & 7 & 8 & 9 \\
\hline \multirow[t]{2}{*}{ wx } & $4.754 * * *$ & & & & & & $3.785^{* *}$ & & \\
\hline & $(3.21)$ & & & & & & $(2.43)$ & & \\
\hline \multirow[t]{2}{*}{ wm } & & $3.029 * *$ & & & & & & 1.976 & \\
\hline & & $(2.41)$ & & & & & & $(1.47)$ & \\
\hline \multirow[t]{2}{*}{ wt } & & & $4.25 * * *$ & & & & & & $3.193 * *$ \\
\hline & & & $(2.90)$ & & & & & & $(2.10)$ \\
\hline \multirow[t]{2}{*}{ intrm_2 } & & & & $0.374 * *$ & & & & & \\
\hline & & & & $(2.17)$ & & & & & \\
\hline \multirow[t]{2}{*}{ intrm_3 } & & & & & $0.448 * *$ & & & & \\
\hline & & & & & $(2.51)$ & & & & \\
\hline \multirow[t]{2}{*}{ intrm_4 } & & & & & & $0.44 * *$ & 0.302 & $0.35^{*}$ & 0.309 \\
\hline & & & & & & $(2.43)$ & $(1.62)$ & $(1.84)$ & $(1.64)$ \\
\hline \multirow[t]{2}{*}{ bd_corr } & 0.116 & 0.092 & 0.106 & 0.096 & 0.104 & 0.107 & $0.121 *$ & 0.105 & 0.114 \\
\hline & $(1.62)$ & $(1.28)$ & $(1.48)$ & $(1.31)$ & $(1.42)$ & $(1.45)$ & $(1.67)$ & $(1.43)$ & $(1.56)$ \\
\hline \multirow[t]{2}{*}{ m_corr } & $0.238 * * *$ & $0.267 * * *$ & $0.247 * * *$ & $0.276^{* * *}$ & $0.273 * * *$ & $0.268 * * *$ & $0.23 * * *$ & $0.255^{* * *}$ & $0.239 * * *$ \\
\hline & $(2.81)$ & $(3.16)$ & $(2.93)$ & $(3.26)$ & $(3.23)$ & $(3.17)$ & $(2.72)$ & $(3.01)$ & $(2.82)$ \\
\hline \multirow{3}{*}{$\begin{array}{l}\text { \# of obs. } \\
\mathrm{R}^{\wedge} 2 \\
\text { root } \mathrm{MSE}\end{array}$} & 144 & 145 & 145 & 141 & 141 & 141 & 141 & 141 & 141 \\
\hline & 0.15 & 0.13 & 0.14 & 0.12 & 0.13 & 0.12 & 0.16 & 0.14 & 0.15 \\
\hline & 0.42 & 0.42 & 0.42 & 0.42 & 0.42 & 0.42 & 0.42 & 0.42 & 0.42 \\
\hline
\end{tabular}

4. B Panel Regression: Fixed Effects

\begin{tabular}{|c|c|c|c|c|c|c|c|c|c|}
\hline & 1 & 2 & 3 & 4 & 5 & 6 & 7 & 8 & 9 \\
\hline \multirow[t]{2}{*}{ wx } & 7.962 & & & & & & 4.294 & & \\
\hline & $(1.09)$ & & & & & & $(0.55)$ & & \\
\hline \multirow[t]{2}{*}{ wm } & & 6.193 & & & & & & 6.956 & \\
\hline & & $(1.41)$ & & & & & & $(1.51)$ & \\
\hline \multirow[t]{2}{*}{ wt } & & & 9.915 & & & & & & 7.779 \\
\hline & & & $(1.32)$ & & & & & & $(0.93)$ \\
\hline \multirow[t]{2}{*}{ intrm_2 } & & & & $0.611 *$ & & & & & \\
\hline & & & & $(1.68)$ & & & & & \\
\hline \multirow[t]{2}{*}{ intrm_3 } & & & & & $0.877 * *$ & & & & \\
\hline & & & & & $(2.27)$ & & & & \\
\hline \multirow[t]{2}{*}{ intrm_4 } & & & & & & $1.077 * *$ & $1.015^{* *}$ & $1.086 * *$ & $0.991^{* *}$ \\
\hline & & & & & & $(2.50)$ & $(2.27)$ & $(2.54)$ & $(2.25)$ \\
\hline \multirow[t]{2}{*}{ bd_corr } & 0.104 & 0.097 & 0.098 & 0.086 & 0.081 & 0.09 & 0.09 & 0.09 & 0.09 \\
\hline & $(1.08)$ & (1.02) & $(1.32)$ & $(0.89)$ & $(0.84)$ & $(0.94)$ & $(0.98)$ & $(0.99)$ & $(0.99)$ \\
\hline \multirow[t]{2}{*}{ m_corr } & 0.055 & 0.061 & 0.057 & 0.050 & 0.048 & 0.036 & 0.040 & 0.043 & 0.039 \\
\hline & $(0.53)$ & $(0.59)$ & $(0.56)$ & $(0.47)$ & $(0.46)$ & $(0.35)$ & $(0.38)$ & $(0.42)$ & $(0.38)$ \\
\hline \multirow{3}{*}{$\begin{array}{c}\text { of obs. } \\
\text { overall } \\
\mathrm{R}^{\wedge} 2 \\
\text { sigma_e }\end{array}$} & 144 & 145 & 145 & 141 & 141 & 141 & 141 & 141 & 141 \\
\hline & 0.12 & 0.08 & 0.10 & 0.06 & 0.07 & 0.06 & 0.10 & 0.08 & 0.10 \\
\hline & 0.41 & 0.41 & 0.41 & 0.41 & 0.41 & 0.40 & 0.41 & 0.41 & 0.40 \\
\hline
\end{tabular}

Note: See the note to Table 3.A 
Table 5. The Effects of Trade Integration on Business Cycle Co-movements (Japan, Hong Kong and Singapore excluded)

5.A Pooled Regression

\begin{tabular}{|c|c|c|c|c|c|c|c|c|c|}
\hline & 1 & 2 & 3 & 4 & 5 & 6 & 7 & 8 & 9 \\
\hline \multirow[t]{2}{*}{ wx } & 5.335 & & & & & & 4.391 & & \\
\hline & $(1.64)$ & & & & & & $(1.34)$ & & \\
\hline \multirow[t]{2}{*}{$\mathrm{wm}$} & & 0.870 & & & & & & -0.644 & \\
\hline & & $(0.30)$ & & & & & & $(-0.22)$ & \\
\hline \multirow[t]{2}{*}{ wt } & & & 5.566 & & & & & & 3.754 \\
\hline & & & $(1.39)$ & & & & & & $(0.90)$ \\
\hline \multirow[t]{2}{*}{ intrm_2 } & & & & 0.341 & & & & & \\
\hline & & & & $(1.61)$ & & & & & \\
\hline \multirow[t]{2}{*}{ intrm_3 } & & & & & $0.469^{*}$ & & & & \\
\hline & & & & & $(2.03)$ & & & & \\
\hline \multirow[t]{2}{*}{ intrm_4 } & & & & & & $0.506^{*}$ & $0.453 *$ & $0.52 *$ & $0.445^{*}$ \\
\hline & & & & & & $(1.99)$ & $(1.77)$ & $(1.97)$ & $(1.69)$ \\
\hline \multirow[t]{2}{*}{ bd_corr } & 0.067 & 0.060 & 0.058 & 0.054 & 0.053 & 0.05 & 0.06 & 0.05 & 0.05 \\
\hline & $(0.79)$ & $(0.69)$ & $(0.69)$ & $(0.63)$ & $(0.62)$ & $(0.59)$ & $(0.64)$ & $(0.61)$ & $(0.58)$ \\
\hline \multirow[t]{2}{*}{ m_corr } & $0.27 * * *$ & $0.289 * * *$ & $0.275^{* * *}$ & $0.272 * * *$ & $0.263 * * *$ & $0.25 * *$ & $0.239 * *$ & $0.248 * *$ & $0.245^{* *}$ \\
\hline & $(2.73)$ & $(2.91)$ & $(2.78)$ & $(2.72)$ & $(2.64)$ & $(2.48)$ & $(2.37)$ & $(2.44)$ & $(2.43)$ \\
\hline \multirow{3}{*}{$\begin{array}{l}\text { \# of obs. } \\
\quad \mathrm{R}^{\wedge} 2 \\
\text { root MSE }\end{array}$} & 111 & 112 & 112 & 110 & 110 & 110 & 110 & 110 & 110 \\
\hline & 0.10 & 0.08 & 0.09 & 0.10 & 0.11 & 0.11 & 0.13 & 0.11 & 0.12 \\
\hline & 0.43 & 0.43 & 0.43 & 0.43 & 0.43 & 0.43 & 0.43 & 0.43 & 0.43 \\
\hline
\end{tabular}

5. B Panel Regression: Fixed Effects

\begin{tabular}{|c|c|c|c|c|c|c|c|c|c|}
\hline & 1 & 2 & 3 & 4 & 5 & 6 & 7 & 8 & 9 \\
\hline \multirow[t]{2}{*}{$w x$} & 6.795 & & & & & & 1.279 & & \\
\hline & $(0.65)$ & & & & & & $(0.12)$ & & \\
\hline \multirow[t]{2}{*}{ wm } & & 6.739 & & & & & & 6.707 & \\
\hline & & $(1.25)$ & & & & & & $(1.23)$ & \\
\hline \multirow[t]{2}{*}{$\mathrm{wt}$} & & & 16.779 & & & & & & 9.051 \\
\hline & & & $(1.22)$ & & & & & & $(0.60)$ \\
\hline \multirow[t]{2}{*}{ intrm_2 } & & & & 0.430 & & & & & \\
\hline & & & & (1.09) & & & & & \\
\hline \multirow[t]{2}{*}{ intrm_3 } & & & & & $0.703 *$ & & & & \\
\hline & & & & & $(1.67)$ & & & & \\
\hline \multirow[t]{2}{*}{ intrm_4 } & & & & & & $0.817^{*}$ & 0.798 & $0.829^{*}$ & 0.708 \\
\hline & & & & & & $(1.70)$ & $(1.56)$ & $(1.73)$ & (1.37) \\
\hline \multirow[t]{2}{*}{ bd_corr } & 0.039 & 0.036 & 0.046 & 0.022 & 0.017 & 0.02 & 0.03 & 0.03 & 0.04 \\
\hline & $(0.34)$ & $(0.32)$ & $(0.41)$ & $(0.20)$ & $(0.16)$ & $(0.22)$ & $(0.24)$ & $(0.31)$ & $(0.32)$ \\
\hline \multirow[t]{2}{*}{ m_corr } & 0.086 & 0.092 & 0.096 & 0.074 & 0.075 & 0.063 & 0.065 & 0.075 & 0.073 \\
\hline & $(0.70)$ & $(0.78)$ & $(0.81)$ & $(0.61)$ & $(0.62)$ & $(0.52)$ & $(0.53)$ & $(0.62)$ & $(0.60)$ \\
\hline \multirow{3}{*}{$\begin{array}{c}\# \text { of obs. } \\
\text { overall } \\
\mathrm{R}^{\wedge} 2 \\
\text { sigma_e }\end{array}$} & 111 & 112 & 112 & 110 & 110 & 110 & 110 & 110 & 110 \\
\hline & 0.07 & 0.02 & 0.07 & 0.07 & 0.08 & 0.08 & 0.09 & 0.05 & 0.08 \\
\hline & 0.41 & 0.41 & 0.41 & 0.42 & 0.41 & 0.41 & 0.41 & 0.41 & 0.41 \\
\hline
\end{tabular}

Note: See the note to Table 3.A 
Table 6. Trends of Intra-Industry Trade in East Asia and Europe (percentage)

\begin{tabular}{lccccccccc}
\hline & & 1980 & & & 1990 & & & 1999 & \\
& IIT-2 & IIT-3 & IIT-4 & IIT-2 & IIT-3 & IIT-4 & IIT-2 & IIT-3 & IIT-4 \\
\hline East Asia & & & & & & & & & \\
China & 17.7 & 14.2 & 13.5 & 60.7 & 55.8 & 51.7 & 45.8 & 42.7 & 39.0 \\
Hong Kong & 45.1 & 42.2 & 41.1 & 58.4 & 57.1 & 55.8 & 56.8 & 56.6 & 56.5 \\
Indonesia & 33.6 & 6.7 & 5.8 & 34.1 & 17.2 & 13.6 & 44.9 & 36.1 & 26.0 \\
Japan & 29.8 & 18.4 & 16.4 & 37.5 & 30.3 & 28.2 & 56.4 & 49.3 & 41.0 \\
Korea & 35.8 & 30.2 & 28.2 & 44.4 & 40.1 & 37.9 & 43.4 & 36.0 & 32.8 \\
Malaysia & 39.6 & 27.3 & 23.1 & 48.6 & 44.1 & 40.1 & 68.9 & 64.9 & 56.5 \\
Philippines & 23.4 & 19.3 & 14.9 & 41.8 & 30.4 & 25.8 & 59.9 & 54.7 & 45.2 \\
Singapore & 34.2 & 25.5 & 22.3 & 57.9 & 47.2 & 42.4 & 74.1 & 68.2 & 61.9 \\
Taiwan & 23.1 & 17.8 & 12.2 & 32.0 & 30.0 & 26.0 & 60.4 & 56.4 & 48.1 \\
Thailand & 30.3 & 24.6 & 22.0 & 41.3 & 37.3 & 34.3 & 49.9 & 46.6 & 42.7 \\
Average & 31.3 & 22.6 & 20.0 & 45.7 & 38.9 & 35.6 & 56.1 & 51.1 & 45.0 \\
& & & & & & & & & \\
Europe & & & & & & & & & \\
Austria & 60.4 & 52.7 & 47.1 & 70.5 & 60.2 & 53.5 & 71.2 & 63.5 & 56.9 \\
Denmark & 58.7 & 50.8 & 44.4 & 66.9 & 56.5 & 49.5 & 72.0 & 63.0 & 53.8 \\
Finland & 49.7 & 43.4 & 40.5 & 59.0 & 54.0 & 48.9 & 63.6 & 51.1 & 45.4 \\
France & 78.2 & 65.9 & 60.0 & 79.3 & 71.2 & 64.3 & 79.4 & 71.7 & 66.1 \\
GBR & 74.9 & 66.8 & 61.1 & 79.1 & 72.3 & 65.5 & 83.2 & 74.3 & 65.9 \\
Germany & 67.1 & 62.7 & 59.4 & 71.6 & 68.0 & 64.5 & 71.1 & 68.2 & 64.1 \\
Greece & 42.6 & 22.0 & 16.5 & 39.1 & 30.5 & 23.2 & 32.4 & 26.1 & 21.0 \\
Ireland & 60.4 & 55.0 & 45.7 & 71.6 & 62.9 & 51.9 & 69.5 & 58.3 & 49.3 \\
Italy & 71.4 & 58.4 & 52.9 & 69.7 & 60.6 & 53.9 & 72.4 & 63.9 & 56.2 \\
Netherlands & 70.7 & 63.0 & 55.9 & 73.3 & 65.8 & 58.9 & 70.8 & 62.3 & 56.7 \\
Norway & 58.4 & 50.6 & 46.3 & 65.1 & 52.5 & 47.6 & 64.5 & 48.4 & 43.2 \\
Portugal & 32.4 & 26.4 & 21.2 & 45.8 & 40.3 & 32.7 & 54.9 & 49.0 & 40.7 \\
Sweden & 65.9 & 58.4 & 54.7 & 71.9 & 64.1 & 59.3 & 77.3 & 66.2 & 61.1 \\
Average & 60.8 & 52.0 & 46.6 & 66.4 & 58.4 & 51.8 & 67.9 & 58.9 & 52.3 \\
\hline & & & & & & & & &
\end{tabular}

